\title{
Effect of Deep Seawater on Expression of $\mu$-Opioid Receptor in Cultured Rat Hippocampal Neurons
}

\| Soo Moon ${ }^{2}$ and Seong-Ho Kim*

${ }^{1}$ Department of Internal Medicine, Inje University College of Medicine, Busan 612-030, Korea

${ }^{2}$ Department of Anatomy, Dongguk University College of Medicine, Gyeongju 780-714, Korea

Received November 4, 2010 /Accepted December 6, 2010

\begin{abstract}
Deep seawater (DSW) generally refers to seawater at depths equal to or greater than 200 meters. DSW is rich in inorganic materials which have attracted attention for its various applications. In this study we investigated the effects of the DSW upwelled from the East Sea, offshore Yang Yang (KangWon-do, Korea), on the expression of 1 -opioid receptor (MOR) of cultured rat hippocampal neurons. Neurons were grown in a minimal essential medium containing $10 \%(\mathrm{v} / \mathrm{v})$ fetal bovine serum and either 25\% (v/v) distilled water, or hardness $(\mathrm{H})$ 800, or H 1000 DSW. Cultures grown in the presence of DSW with H 800 and H 1000 exhibited robust MOR immunoreactive signals in both neurons and astrocytes. Interestingly, the increase in MOR immunoreactive signals was more dramatic in astrocytes than in neurons. Statistical analysis revealed that the relative intensities for MOR clusters increased approximately 4-fold in astrocytes cultured in H 800 and H 1000 media. These increases were statistically very significant $(p<0.001)$. In contrast, the increase in intensities for MOR immunoreactive signals was relatively less dramatic in neurons, where only the increase in the H 1000 culture was statistically very significant $(p<0.001)$. These results indicated that DSW promotes expression of MOR in both neurons and astrocytes, and more significantly in the latter.
\end{abstract}

Key words : Deep seawater, hippocampal neuron, mu-opioid receptor, astrocytes, fibromyalgia

\section{Introduction}

Deep seawater (DSW; deep ocean water) refers to water that is extracted from the ocean, usually at depths of 200 meters or more. Sunlight does not reach at such depths. Due to lack of photosynthesis, DSW is relatively free of microorganisms such as phytoplanktons. Wealth in various minerals including indispensable trace elements in DSW has demonstrated their usefulness in various applications [6]. Some experimental evidence supporting the efficacy of DSW are available by now. DSW controls the increase of serum lipid values [total cholesterol and low density lipoprotein (LDL) cholesterol] of cholesterol-fed rabbits, and promotes the reduction of serum lipid hyperlipemia rabbits [20]. DSW is useful for the prevention of hyperlipidemia and arteriosclerosis compared to the surface seawater by reduction of the LDL cholesterol level and enhancement of GPx activity [12]. DSW could improve cardiovascular hemodynamics [7] and indices for cancer chemoprevention [15].

We have been studying the effects of the DSW upwelled

\footnotetext{
${ }^{*}$ Corresponding author

Tel : +82-51-797-2044, Fax : +82-51-797-2046

E-mail : junjan@paik.ac.kr
}

from the East Sea, off-shore YangYang (KangWon-do, Korea) on the cultured rat hippocampal neurons. Using this model system we recently tested the efficacy of DSW on morphological differentiation, and found that, although DSW had no effect on initial morphological differentiation $(17 \mathrm{hr}$ post-plating), low hardness (H) (0 and 200) DSW reduced dendritic branching resulting in bipolar-like morphologies in extreme cases [10]. H 600 DSW was more or less same as control groups, and H 1,000 DSW doubled the number of dendritic branches indicating that DSW with appropriate hardness ameliorates neuronal health.

Our other previous study showed the effects of the DSW on the synaptic maturation of cultured rat hippocampal neurons [9]. The examination of DIV21 showed that coupling rates of synaptic vesicle 2 and N-methyl-D-aspartate (NMDA) receptor (NR) 2B were significantly increased in neurons grown in the presence of H 800 and H 1000 DSW. That study suggests that DSW promotes the formation of excitatory postsynaptic signal transduction NMDA-associated complexes and functional synapses. NMDA and opioid receptor systems are considered central to nociception and antinociception. The relationship between these systems is not only functional but also spatial within multi- 
ple central nervous system regions (CNS) [11]. These receptor systems are found concentrated in presynaptic and postsynaptic sites of the dorsal horn (particularly lamina II), suggesting a close functional relationship [5]. Opioids can directly and indirectly modulate NR activity and affect the NR mediated calcium influx into neurons $[2,16,19,21]$.

In this study we investigated the effects of the DSW on the mu opioid receptor (MOR) expression of cultured rat hippocampal neurons.

\section{Materials and Methods}

\section{DSW}

The DSW was pumped up from a depth of 1,100 $\mathrm{m}$ off YangYang (Kang Won-do, Korea) was desalinated and concentrated by reverse osmosis. The desalinated water was defined as hardness $(\mathrm{H})$ zero $(\mathrm{H}$ 0). The mineral ingredient content of the H 4,000 DSW, which was manufactured by dilution of the DSW, is shown elsewhere [15], and obtained from Waterbis Co., Ltd (Ansan, Korea).

\section{Antibodies}

The following antibodies were used. MOR (1:5,000; rabbit polyclonal, Millipore, Billerica, MA, USA). Anti-Glial fibrillary acidic protein (GFAP) (1:500; Millipore, Billerica, MA, USA). Postsynaptic density protein (PSD) 95 (1:1,000; chicken polyclonal UCT-C1, a kind gift from Dr. Randall Walikonis, University of Connecticut, CT, USA).

\section{Neuronal culture}

Embryonic day 18 (E19) rat hippocampal cells were dissociated by triturating trypsin-treated tissues, and were plated on poly-DL-lysine-coated coverslips $(1,000 \sim 1,500$ cells/ $\mathrm{mm}^{2}$ ) in the minimal essential medium (MEM; Gibco, \#11700-077) containing 10\% (v/v) fetal bovine serum (Gibco \# 26140-079), 25\% (v/v) DSW of various $\mathrm{H}$, and $25 \mu \mathrm{M}$ glutamate, as previously described $[1,4]$. One third of the culture media was replaced with the same fresh one but glutamate every 3 days.

\section{Immunocytochemistry}

Cells were fixed through the PFA/MeOH fixation method [13]. Coverslips were rinsed briefly in phosphate buffered saline (PBS) and with $4 \%$ paraformaldehyde (PFA) in PBS at room temperature (RT) for $10 \mathrm{~min}$. Coverslips were rinsed in PBS and then incubated in $-20^{\circ} \mathrm{C}$ methanol at $-20^{\circ} \mathrm{C}$ for
$20 \mathrm{~min}$. The cells were then rinsed once with PBS and blocked overnight at $4{ }^{\circ} \mathrm{C}$ in preblocking buffer [5\% normal goat serum, $0.05 \%$ Triton X-100 in H-PBS $(450 \mathrm{mM} \mathrm{NaCl}$ and $20 \mathrm{mM}$ phosphate buffer, $\mathrm{pH}$ 7.4)]. Primary antibodies were diluted in preblocking buffer $(250 \mu \mathrm{l}$ per well of 24 -well culture plate), replaced with preblocking buffer, and incubated overnight at $4^{\circ} \mathrm{C}$. Coverslips were rinsed $(15 \mathrm{~min}$ $\times 3)$ in preblocking buffer, and incubated with secondary antibodies [Alexa Fluor 488-conjugated goat anti-mouse, Alexa Fluor 568 conjugated-goat anti-rabbit, and Alexa Fluor 647-conjugated goat anti-chicken IgG (each diluted 1:1,000 in blocking buffer; Invitrogen)] at RT for 1-2 hr. Coverslips were rinsed once in preblocking buffer for $15 \mathrm{~min}$, twice in PBS, and mounted on slides with $4 \%$ n-propylgallate in $90 \%$ glycerol and $10 \%$ sodium carbonate buffer $(\mathrm{pH}$ 8.7).

\section{Fluorescence light microscopy}

A Leica Research Microscope DM IRE2 (Leica Microsystems AG, Wetzlar, Germany) equipped with filter systems I3 S, N2.1 S and Y5 was used to capture light and fluorescent microscopic images. Digital images were acquired with low power (10X) and a HCX PL FL 100X oil-immersion lens and a high-resolution CoolSNAP ${ }^{\mathrm{TM}} \mathrm{CCD}$ camera (Photometrics Inc., Germany) under the control of a computer equipped with FW4000 (Leica) software. Images $(1388 \times 1039$ pixels) were processed with the use of Photoshop 5.0 (Adobe Systems).

\section{Histograms and surface plots}

Using an Adobe PhotoShop software (version 5.0), fluorescence images were converted into a gray scale mode (value from 0 to 255), and inverted so that IR signals become dark. Histograms and surface plots (wireframe mode) were produced using a Scion Image software (Beta 4.03; Scion Corp., Frederick, MD, USA) after removing backgrounds through the $2 \mathrm{D}$ rolling ball mode.

\section{Measurement of IR signal densities}

To compare the relative strength of IR signals, images were converted to a gray scale mode ( $0 \sim 255$ scale), inverted, and backgrounds were removed through the $2 \mathrm{D}$ rolling ball mode. A small circular area including one IR puncta was selected and the mean density of the selected area was measured using a Scion Image software. The circle was dragged to other punctae and the densities were measured. 


\section{Analysis}

For relative intensities of MOR IR signals, mean densities of about 100 150 clusters from 3-5 dendritic segments were measured and expressed as mean \pm SD. Multiple pairwise comparisons for statistical significance were evaluated by Kruskal-Wallis one-way ANOVA, and the differences between groups by Mann-Whitney $U$-test. The $p$ values of less than 0.05 and 0.01 were considered to be significant and very significant, respectively.
Results

Hippocampal cultures were double-labeled with antibodies against MOR and either PSD 95 or GFAP, specific markers for neurons or astrocytes, respectively. Fluorescent microscopic images of MOR/PSD 95 double-labeling of hippocampal neurons grown in control media were shown in Fig. 1A. MOR immunoreactive signals were distributed throughout somatodendritic domains, and formed clusters

\section{Control media}

A
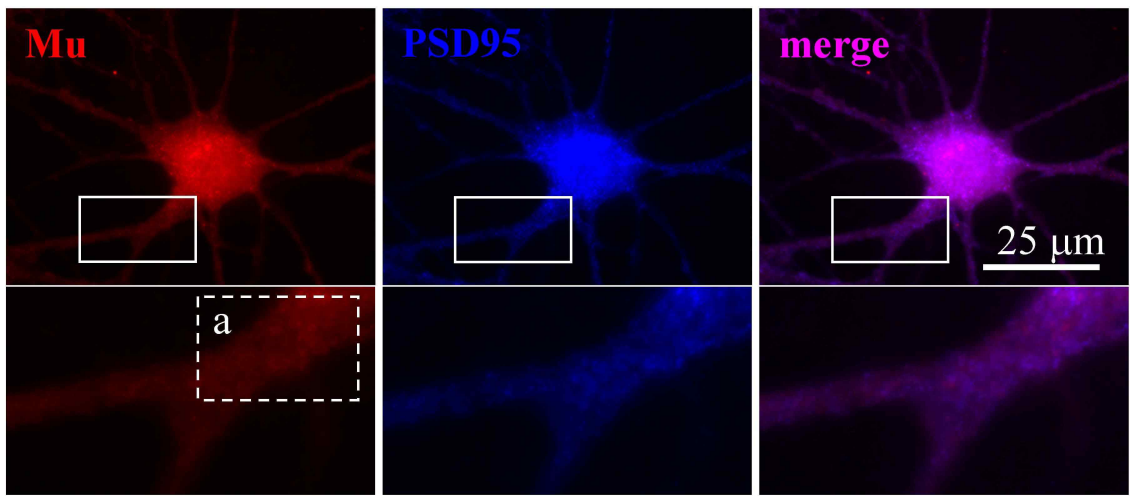

B
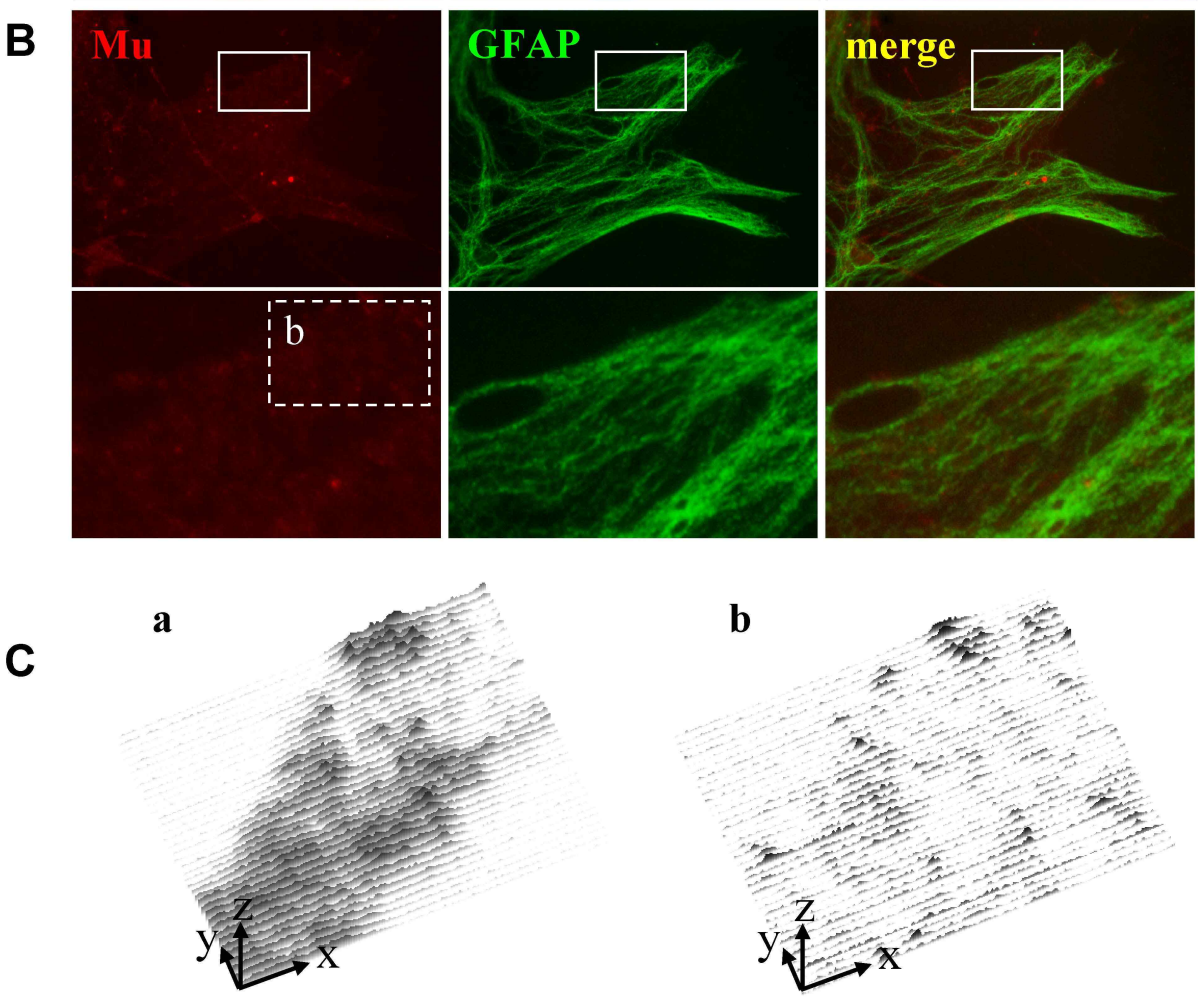

Fig. 1. Expression of Mu-opioid receptors (MOR) in the control media. Cultured cells were triple-labeled with antibodies against MOR, PSD95, and GFAP. Fluorescence micrographs of a neuron (A) and an astrocyte (B) were shown in single and merge images. Boxed areas were shown enlarged in insets. The surface plots of the boxed areas a and $b$ of each inset for MOR expressions were shown in panel C. Scale bar; $25 \mu \mathrm{m}$. 
that were not overlapped with those of PSD 95 (Fig. 1A, insets). Fluorescent microscopic images for a sister culture that is double-labeled with antibodies against MOR and GFAP were shown in Fig. 1B. Similar to neuronal stainins, MOR immunoreactive signals formed clusters throughout astrocyte's cytoplasms (Fig. 1B, insets). However, as shown by the surface plots, the intensities for MOR clusters were not very strong in both neuron and astrocyte (Fig. 1C). In contrast, cultures grown in the presence of DSW with $\mathrm{H} 800$ (Fig. 2) and H 1,000 (Fig. 3) exhibited robust MOR immunoreactive signals in both neurons and astrocytes. Interestingly, the increase in MOR immunoreactive signals was more dramatic in astrocytes (box b's in insets of Figs. 2 and 3) than in neurons (box a's in insets of Figs. 2 and 3), as shown evidently in surface plots (Figs. 2C and 3C). Statistical analysis revealed that the relative intensities for MOR clusters increased approximately 4-fold in astrocytes cultured in $\mathrm{H} 800$ and H 1000 media (from $13.3 \pm 4.9$ to $52.0 \pm 15.1$ and $47.3 \pm 13.1$, respectively; $n=50 \sim 70)$. These increases were statistically very significant $(p<0.001)$ (Fig. 4). In contrast, the increase in intensities for MOR immunoreactive signals was relatively less dramatic in neurons; from $22.0 \pm 6.8$ in control medium to $24.1 \pm 4.6$ and $34.7 \pm 11.3$ in $\mathrm{H} 800$ and $\mathrm{H} 1000$ media, respectively, where the increase in the $\mathrm{H} 1000$ culture was statistically very significant $(p<0.001)$ (Fig. 4).

\section{DSW-H 800}
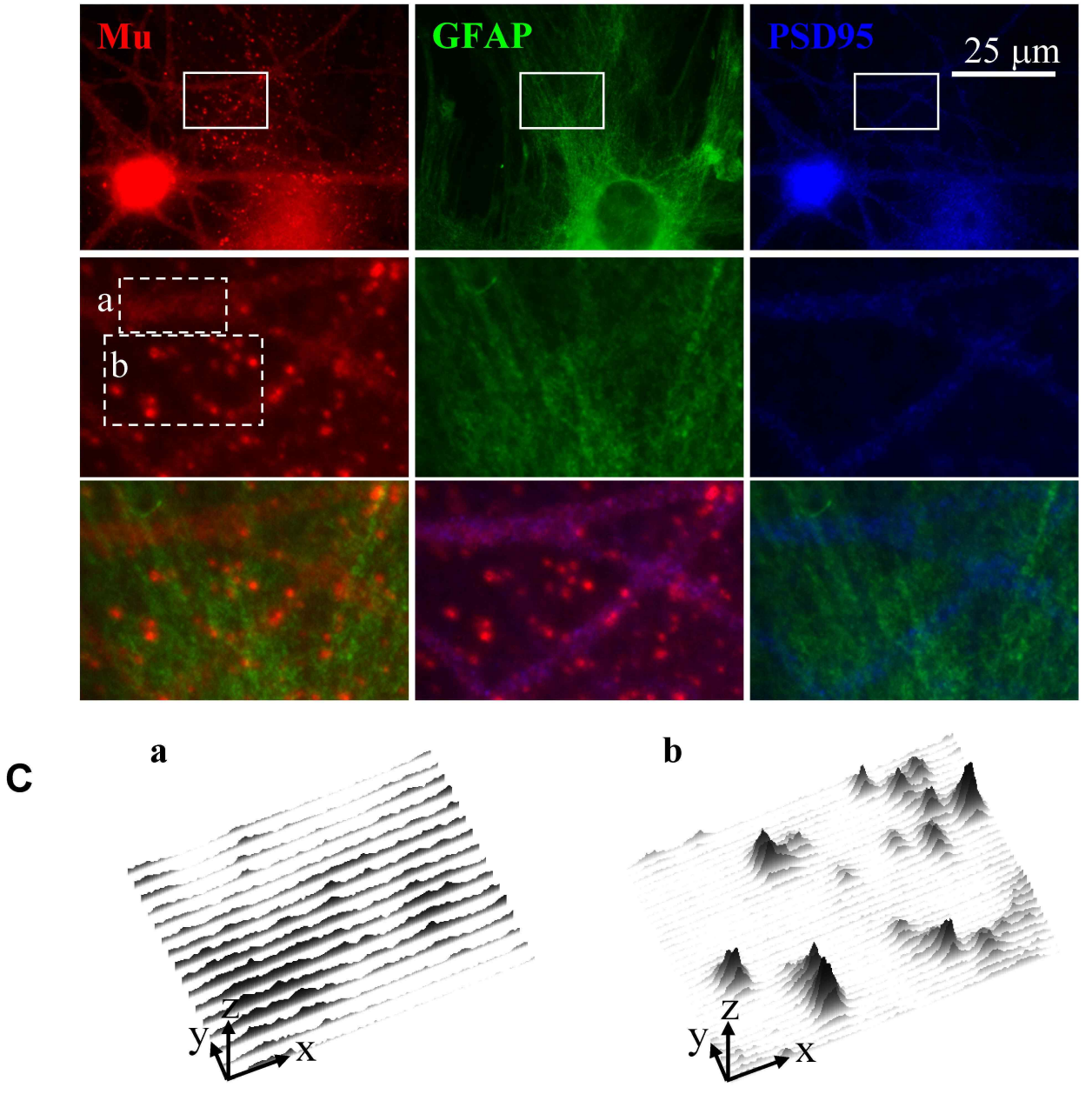

Fig. 2. Expression of Mu-opioid receptors (MOR) in the $\mathrm{H} 800$ media. Cultured cells were triple-labeled with antibodies against MOR, PSD95, and GFAP. Boxed areas were shown enlarged in single channels (middle row) or in merge (bottom row). The boxed areas $a$ and $b$ in the middle row represents the expression of MOR in a neuron and an astrocyte, respectively, and their surface plots were shown in the panel C. Scale bar; $25 \mu \mathrm{m}$. Note significant increases in the MOR signal intensities in both neuron and astrocytes, being more significant in astrocytes. 


\section{DSW-H 1,000}

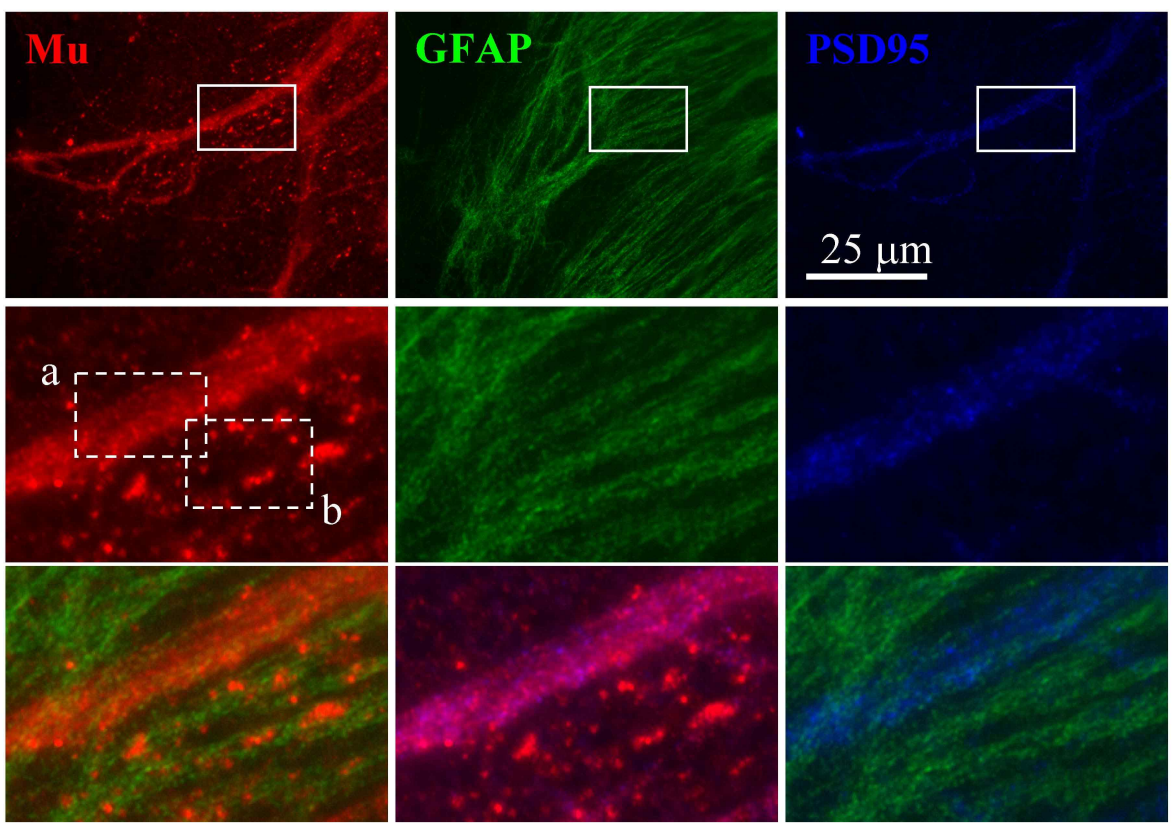

C

$\mathbf{a}$

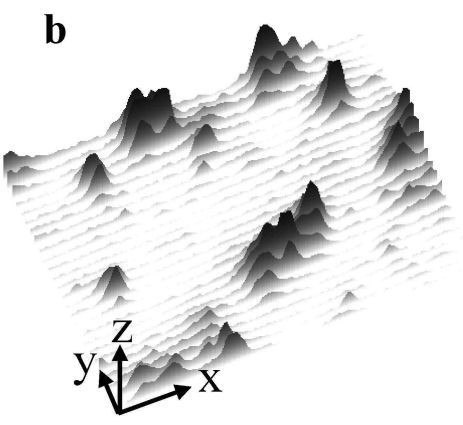

Fig. 3. Expression of Mu-opioid receptors (MOR) in the H 1000 media. Immunocytochemistry, layouts, and labels are same as in Fig. 2. Note significant increases in the MOR signal intensities in both neuron and astrocytes, being more significant in astrocytes.

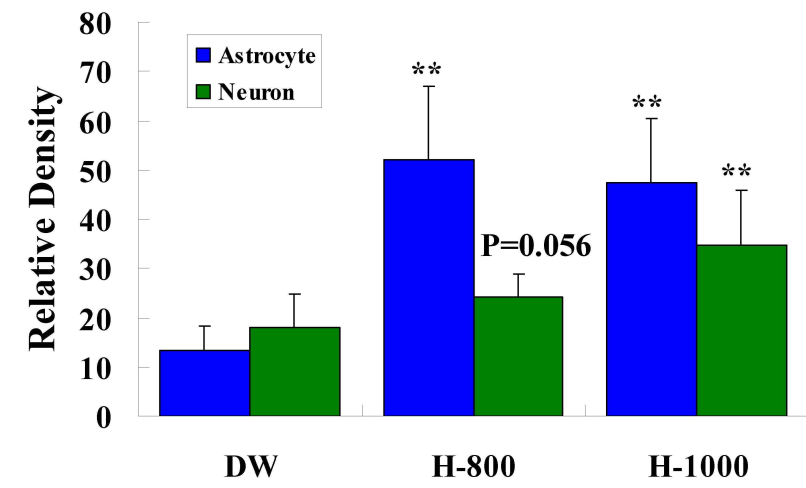

Fig. 4. Relative intensities of Mu-opioid receptors (MOR) IR signals. The IR signal intensities of MOR clusters were measured in 0-255 gray scales. DW=distilled water. Statistic significance was assessed by Mann-Whitney U-test. ${ }^{* *}, p<0.001$.

\section{Discussion}

We carried out immunocytochemistry to investigate whether DSW affects the expression of MOR. These results indicate that DSW promotes expression of MOR in both neurons and astrocytes, more significantly in the latter. Astrocytes express functional $\mathrm{mu}$, delta, and kappa opioid receptors in a region-specific manner $[3,14,18]$. There is very little on possible mechanisms involved in this study. It would be helpful if any of the individual minerals contained within DSW been assessed for their effects on MOR expression. It would be also very interesting if a single mineral or combination of minerals could be identified which would replicate the observed benefits of DSW. 
The East Sea is connected with four other open seas through narrow and shallow straits. Due to relatively isolated oceanography, it is a bowl-shaped 'Ocean Miniature' where water exchange between the East Sea and other connected oceans are very limited. Therefore, it is believed that more than $90 \%$ of all East Sea water is DSW. In the previous report we showed that the rat hippocampal neurons grown in the presence of the East Sea DSW are healthier and more dendritic branches are formed than distilled water groups [10]. In this study we investigated whether the health in gross morphology accompanies synaptic 'health' or maturation. Because DSW [25\% (v/v)] needs to be added into the culture medium, culture media were made using a powder form [minimal essential medium (MEM; Gibco, \#11700-077) containing 10\% (v/v) fetal bovine serum (Gibco \# 26140-079). Our other previous study showed the effects of the DSW on the synaptic maturation of cultured rat hippocampal neurons [9]. Immunocytochemical examination of DIV21 showed that PSD 95, $\alpha$-isoform of type II Ca ${ }^{2+} /$ calmodulin-dependent protein kinase and synGAPa1 clusters were strengthened and coupling rates of Synaptic vesicle 2 and NR 2B were significantly increased in neurons grown in the presence of H 800 and H 1000 DSW. Our results indicate that DSW promotes the formation of excitatory postsynaptic signal transduction NMDA- or MAGUK-associated complexes and functional synapses [9].

The acidic saline animal model of pain has been suggested to mimic chronic widespread pain such as fibromyalgia. In this model, repeated intramuscular injections of acidic saline produce a widespread hyperalgesia that persists without evidence of significant peripheral tissue damage or inflammation, and is believed to be centrally maintained [17]. Kim et al. [8] examined the changes of pain-related neurotransmitters in specific brain regions of this model after DSW drinking. Preliminary results showed that compared to controls, acid injected rats demonstrated strong expression of serotonin in red and raphe nucleus. Acid injected rats showed significant reductions of the serotonin expression in red and raphe nucleus after DSW drinking. This study suggests DSW might be helpful for pain and anxiety [8].

In this study we showed that DSW upwelled in the off-shore YangYang promotes expression of MOR in both neurons and astrocytes. Considering increased MOR expression in CNS of rats and significant reductions of the serotonin expression in red and raphe nucleus of acid injected rats [8] after DSW treatment, it is believed that DSW can be helpful for pain control.

\section{References}

1. Brewer, G. J., J. R. Torricelli, E. K. Evege, and P. J. Price. 1993. Optimized survival of hippocampal neurons in B27-supplemented Neurobasal, a new serum-free medium combination. J. Neurosci. Res. 35, 567-576.

2. Chapman, V., J. E. Haley, and A. H. Dickenson. 1994. Electrophysiologic analysis of preemptive effects of spinal opioids on N-methyl-D-aspartate receptor-mediated events. Anesthesiol. 81, 1429-1435.

3. Eriksson, P. S., E. Hansson, and L. Rönnbäck. 1991. Mu and delta opiate receptors in neuronal and astroglial primary cultures from various regions of the brain--coupling with adenylate cyclase, localisation on the same neurones and association with dopamine (D1) receptor adenylate cyclase. Neuropharmacol. 30, 1233-1239.

4. Goslin, K., H. Asmussen, and G. Banker. 1998. Rat hippocampal neurons in low-density culture, pp. 339-370, In Banker, G. and K. Goslin (eds.), Culturing nerve cells. MIT Press, Cambridge.

5. Gracy, K. N., A. L. Svingos, and V. M. Pickel. 1997. Dual ultrastructural localization of mu-opioid receptors and NMDA-type glutamate receptors in the shell of the rat nucleus accumbens. J. Neurosci. 17, 4839-4848.

6. Hachmuth, C. 1991. On the properties of deep seawater at Keahole point. In: Proceeding of the International Forum on Deep Sea Water, pp. 46-49, Japan.

7. Katsuda, S., T. Yasukawa, K. Nakagawa, M. Miyake, M. Yamasaki, K. Katahira, M. Mohri, T. Shimizu, and A. Hazama. 2008. Deep-sea water improves cardiovascular hemodynamics in Kurosawa and Kusanagi-Hypercholesterolemic (KHC) rabbits. Biol. Pharm Bull. 31, 38-44.

8. Kim, S. H., N. H. Choi, I. S. Park, and K. S. Nam. 2008. Serotonin changes in specific brain regions of fibromyalgia animal model after deep-sea water drinking. J. Korean Rheumat. Assoc. 15, 110-117.

9. Kim, S. H., H. Lee, K. S. Nam, Y. H. Shon, and I. S. Moon. 2008. Promotion of synaptic maturation by deep seawater in cultured rat hippocampal neurons. J. Life Sci. 18, 1479-1484.

10. Lee, H., K. S. Nam, Y. H. Shon, and I. S. Moon. 2008. Deep seawater increases dendritic branches of cultured rat hippocampal neurons. J. Life Sci. 18, 897-901.

11. Mao, J. 1990. NMDA and opioid receptors: their interactions in antinociception, tolerance and neuroplasticity. Brain Res. Rev. 30, 289-304.

12. Miyamura, M., S. Yoshioka, A. Hamada, D. Takuma, J. Yokota, M. Kusunose, S. Kyotani, H. Kawakita, K. Odani, Y. Tsutsui, and Y. Nishioka. 2004. Difference between deep seawater and surface seawater in the preventive effect of atherosclerosis. Biol. Pharm Bull. 27, 1784-1787.

13. Moon, I. S., S. J. Cho, I. Jin, and R. A. Walikonis. 2007. A simple method for combined fluorescence in situ hybrid- 
ization and immunocytochemistry. Mol. Cells 24, 76-82.

14. Ruzicka, B. B., C. A. Fox, R. C. Thompson, F. Meng, S. J. Watson, and H. Akil. 1995. Primary astroglial cultures derived from several rat brain regions differentially express $\mathrm{mu}$, delta and kappa opioid receptor mRNA. Brain Res. Mol. Brain Res. 34, 209-220.

15. Shon, Y. H., M. K. Kim, J. S. Jang, E. J. Jung, and K. S. Nam. 2008. Effect of deep sea water on phase I, phase II and ornithine decarboxylase. J. Life Sci. 18, 381-386.

16. Sivilotti, L. G., G. Gerber, B. Rawat, and C. J. Woolf. 1995. Morphine selectively depresses the slowest, NMDA-independent component of C-fibre-evoked synaptic activity in the rat spinal cord in vitro. Eur. J. Neurosci. 7, 12-18.

17. Sluka, K. A., A. Kalra, and S. A. Moore. 2001. Unilateral intramuscular injections of acidic saline produce a bilateral, long-lasting hyperalgesia. Muscle Nerve 24, 37-46.

18. Stiene-Martin, A., R. Zhou, and K. F. Hauser. 1998. Regional, developmental, and cell cycle-dependent differences in $\mathrm{mu}$, delta, and kappa-opioid receptor expression among cultured mouse astrocytes. Glia 22, 249-259.

19. Vaughan, C. W. and M. J. Christie. 1997. Presynaptic inhibitory action of opioids on synaptic transmission in the rat periaqueductal grey in vitro. J. Physiol. 498, 463-472.

20. Yoshioka, S., A. Hamada, T. Cui, J. Yokota, S. Yamamoto, M. Kusunose, M. Miyamura, S. Kyotani, R. Kaneda, Y. Tsutsui, K. Odani, I. Odani, and Y. Nishioka. 2003. Pharmacological activity of deep-sea water: examination of hyperlipemia prevention and medical treatment effect. Biol. Pharm Bull. 26, 1552-1559.

21. Zhang, K. M., X. M. Wang, and S. S. Mokha. 1996. Opioids modulate N-methyl-D-aspartic acid (NMDA)-evoked responses of neurons in the superficial and deeper dorsal horn of the medulla (trigeminal nucleus caudalis). Brain Res. 719, 229-233.

\section{초록 : 배양된 쥐 해마신경세포에서 $\mu-$ 아편양 수용체의 발현에 대한 해양심층수의 영향}

\section{문일수 ${ }^{2} \cdot$ 김성호 ${ }^{*}$}

( ${ }^{1}$ 인제대학교 의과대학 내과학교실, ${ }^{2}$ 동국대학교 의과대학 해부학교실)

해양심층수는 깊이 $200 \mathrm{~m}$ 정도 혹은 그 이상의 해수를 말한다. 해양심층수는 무기물질이 풍부하여 여러 분야 적용을 위해 많은 관심이 쏠리고 있다. 본 연구에서는 동해 양양 부근에서 취수한 해양심층수에서 배양된 쥐 해 마신경세포의 $\mu$-아편양 수용체 발현에대한 영향을 조사하였다. 경도 800 및 1,000 심층수가 $25 \%(\mathrm{v} / \mathrm{v})$ 포함된 minimal essential media에서 해마신경세포를 배양해 대조군(증류수 첨가)과 비교하였다. 경도 800 및 1000심층 수 첨가 배양액에서 배양된 신경세포 및 별아교세포에서 $\mu$-아편양 수용체의 면역반응 신호가 매우 증가했다. 흥 미롭게도 신경세포보다 별아교세포에서 $\mu$-아편양 수용체의 면역반응 신호 증가가 더 뚜렷했다. 통계 분석시 경도 800 및 1000에서 배양된 별아교세포에서 $\mu$-아편양 수용체 군에 대한 상대적 강도가 약 4 배 증가했다. 이런 증가는 통계적으로 매우 유의했다( $p<0.001)$. 대조적으로 신경세포에선 이런 증가가 상대적으로 덜 뚜렷하였고, 경도 1000 배양에서만 통계적으로 유의하였다( $\beta \times 0.001)$. 이 결과들은 심층수가 신경세포 및 별아교세포에서 $\mu$-아편양 수용 체의 발현을 항진 시킨다는 것을 나타내었다. 